Ks. Bogusiaw Nadolski TChr.

\title{
APOLOGIE W CELEBRACJI EUCHARYSTYCZNEJ JAKO POZASAKRAMENTALNE FORMY POKUTY
}

W VIII w. w dokumentach liturgii galijskiej spotykamy dosyc dziwną, dotychczas nieznaną formę modlitw zwanych apologie. Modlitwy te noszą także inne nazwy jak: confessio, indulgentia, excusatio, ante altare, confessio sancta peccatorum, confessio sancta penitentis, confessio peccatoris, oratio de conscientiae reatu ante altare, excusatio sacerdotis, lub oratio sancti Ambrosi, sancti Augustini, sancti Isidori, albo też po prostu orationes ante missam.

Najbardziej powszechną stało się jednak określenie ,apologia”. Chociaż apologie stanowią bardzo charakterystyczne zjawisko w życiu liturgicznym, nie doczekały się jednak dotychczas całościowego opracowania. Nadal skazani jesteśmy na opracowania encyklopedyczne i leksykalne 1 .

\section{ZBIORY APOLOGII}

Najstarsze sakramentarze leoniński i galezjański nie posiadają apologii. Nie znajdujemy ich również w nastarszych Ordines Romani. Missale Gothicum zawiera tylko jedną, podobnie mszał z Bobbio. Natomiast obfitują w apologie księgi liturgii celtyckiej, mozarabskiej, księgi monastyczne z IX i XI w. Najwięcej apologii zawiera Missa Illyrica (dokument wydany przez protestanta Flaciusa Illyricusa w 1557 r. w. Strassburgu). Mrówczej pracy benedyktyna S. Martene ${ }^{2}$ zawdzięczamy najobszerniejszy zbiór apologii z różnych mszałów i sakramentarzy.

Apologia jest to wyznanie win i niegodności połączone $z$ prośba o przebaczenie, wyznanie dokonywane przez wiernych, a zwłaszcza przez celebransa w czasie Mszy św. ${ }^{3}$ Dla zobrazowania stylu i ducha apologii przytoczymy w całości tekst najstarszej z nich zachowanej w Missale Gothicum. ,Przed Obliczem-Twojej Nieskończoności i przed oczami Twojej Niewymowności o Majestacie godny czci, to znaczy przed Twoim świętym Obliczem Wielki Boże, najdoskonalszej świętości i potęgi, Wszechmocny Ojcze, chociaż z należną czcią, ale bez usprawiedliwiającego tytułu zbliżam się do Ciebie jako biedny żebrak i zjawiam się jako świadek obciążonego winą sumienia. Oskarżam się i nie usprawiedliwiam, ale wobec świadków wyznaję Tobie, Bogu memu własną niesprawiedliwość. Masz mnie jako przyznającego się do winy

1 F. Cabrol, Apologies. DACL T. I. s. 2591-2601. LThK I. 731. Encyclop. Cath. 1948. I. 1669.

2 S. M a r te n e, De antiquis Ecclesiae Ritibus. Paris 1700-1706.

3 Por. F. Cabrol, Dz. cyt. 2591, a także LThK I. 731 oraz Encyklopedia katolicka 1 Lublin 1973. 786. 
i jeszcze nie oczyszczonego. Przybądź przeto, przybądź, niewypowiedziana Dobroci, przebacz, przebacz, przebacz proszącemu Boże łaskawy, wysłuchaj, wysłuchaj, wysłuchaj mnie błagam słowami tego syna Twojego wołającego: „Ojcze, Wieczny Boże, zgrzeszyłem przeciwko Tobie i przeciw niebu... ${ }^{4}$.

Apologie odmawiano w różnych „miejscach" w czasie Mszy św. ${ }^{5}$. I tak dokumenty przewidują odpowiednie apologie przed ubieraniem się do Mszy św. w czasie wchodzenia do kościoła, po ucałowaniu ołtarza, w czasie Kyrie, Gloria. Jungmann zauważa, że Gloria intonował celebrans, zwykle mówił je lub śpiewal w dalszym ciągu. ${ }^{5 a}$ Nie było to jednak wyraźnie nakazane. W okresie jednak rozkwitu apologii celebrujący odmawiał ap̉ologie również w czasie Gloria. Z życiorysu św. Tomasz z Canterbury ( $\dagger$ 1170) dowiadujemy się, że święty ten odmawial apologie w czasie śpiewu introitu. Przewidziane są również apologie po kolekcie, w czasie „Wierzę", przed kazaniem, po kazaniu, w czasie śpiewów międzylekcyjnych po Orates fratres, w czasie przygotowania darów, które rozpoczynano podczas śpiewu, podczas Lavabo, bezpośrednio przed przyjęciem ofiar - ut dignus sit accedere ad altare et ad tactum oblatorum. Przewidziane sa nawet apologie podczas Sanctus. Po Sanctus stosowano moment ciszy. Galia jednak, jak wiemy, nie tolerowała ciszy, dlatego również po Sanctus spotykamy apologie. Missa Illyrica podaje 3 formuły. Niekiedy na tym miejscu przewidziane jest odmówienie Munda cor, Aperi Domine os meum, lub Christe audi nos. Nie odbyło się także bez apologii po konsekracji, chociaż ciągle przypominano nakazy , bez dodatków w kanonie". Jungmann zauważa, że osobista modlitwa po konsekracji była tolerowana. Manuskrypt Stuttgardzki z w. XV w objaśnieniach Mszy św. grozi ekskomunika kapłanowi, który odważy się mówić w czasie podniesienia Deus propitius esto mihi peccatori, lub Propitius esto peccatis nostris propter nomen tuum Domine lub inne ${ }^{6}$. Odmawiano wreszcie apologie przed komunią św. czy w czasie komunii wiernych.

Mimo swej liczebności i wszechobecności apologie nie należały do istoty Mszy św. i takie istniało przekonanie. Uważano je za element dodatkowy. Powstaje pytanie, ile $\mathrm{z}$ apologii było odmawianych w czasie jednej z Mszy św.? Problem ilości pozostaje do końca nie wyjaśnionym. Wydaje się, że liczba pozostawiona była osobistej pobożności celebransa. Warto zauważyć, że niektóre źródła np. mozarabskie przewidują apologie przede wszystkim we mszach (ale nie wylącznie) zatytułowanyech "quam pro se sacerd'ss celebrat".

4 Cyt. za F. Ca brol, dz. cyt. 2592.

5 Zab. J. A. J ungmann, Missarum Sollemnia (tłum. fr.) Paris 1950. T. I. s. $111 \mathrm{nn} .127 \mathrm{nn}$. 143 . T. II. s. $18,21,39,48,57,77,116,211,329,334$, 372, 379. T. III. s. 39, 49, 132, 168.

5a J. A. J un g m a n n, dz. cyt. T. II. s. 116 dop. 49.

6 J. A. J ung m a n n, dz. cyt. T. III. s. 132 . 
Apologie stanowią obcy duchowi liturgii rzymskiej gatunek lite- . racki. Trudno je zakwalifikować do grupy kolekt, prefacji czy téz litanii. Formułowane są w stylu dowolnym, swobodnym, nie krępują się żadnymi regułami, obcy im jest cursus. Charakterem swoim zbliżają się do kolekt ${ }^{7}$.

\section{KLASYFIKACJA 8}

Nie jest rzeczą łatwą dokonać odpowiedniego podziału i klasyfikacji apologii, a to ze względu na ich wzajemny wpływ, zależność $\mathrm{w}$ sformułowaniach. Niektóre są powtórzone dosłownie, inne częściowo lub w nieco zmodyfikowanej formie. Szczególne pokrewieństwo wykazują apologie celtyckie i mozarabskie.

Ogólnie przyjął się następujący podział:

1. Apologie najstarsze przekazane przez Missale Gothicum. Należy do nich cytowana powyżej apologia Ante tuae immensitatis conspectu. Pochodzi ze Mszy paschalnej odmawiana była po Benedictus. Podaje ją również wiele innych mszałów; chociaż nie zawsze na tym samym miejscu, np. Missa Illyrica zamieszcza ją w czasie śpiewu responsoryjnego. Do tej grupy zalicza się również znaną modlitwę św. Ambrożego Ante conspectu, określaną niekiedy nie jako apologia lecz jako missa lub illatio. Liturgia mozarabska podaje ją jako kolektę.

Oto niektóre tytuły innych apologii należące do tej samej grupy: Ad Tuum'altare concurro

Deus qui me indignum

Convertere ad me Domine

Christe Domine qui penitentibus viam

2. Drugą grupę stanowią apologie mozarabskie, najczęściej występujące we Mszach, które kapłan ofiaruje za samego siebie.

3. Do trzeciej zalicza się apologie celtyokie pokrewne mozarabskim. Zebral je i wydał P. Knypers w Book of Cerne. Wśród tych apologii znajdujemy apologię do Sanctus zaczynającą się od słów: Memento mei Domine et miserere.

4. Jako czwartą grupę wymienia się apologie zawarte w sakramentarzu gregoriańskim.

Wykaz apologii rozpoczyna napis: Incipiunt apologiae.

\section{POWSTANIE APOLOGII}

Problem powstania apologii jest mocno skomplikowany i nadal pozostaje przedmiotem dociekań. Na zjawisko apologii złożyły się niewątpliwie liczne przyczyny. Wskażemy na niektóre:

7 F. Cabrol, dz. cyt. 2600.

8 Podaję za F. Cabrol, dz. cyt. 2592-2599. 
1. Żywa wiara $w$ obliczy Bożego działania $w$ eucharystii kazała św. Pawłowi podyktować słowa: probet autem seipsum homo (1 Kor 11, 17-29). I chyba trzeba tu koniecznie sięgnąc jeśli pytamy o najdalsze początki apologii 9 .

2. Czytając Didache dostrzegamy, że mówi ono aż trzykrotnie o wyznaniu grzechu, o pokucie i pojednaniu.

,W zgromadzeniu wyznasz grzechy swoje i nie pójdziesz na modlitwę ze złym sumieniem $(4,14)$. Niech przyjdzie laska i niech przeminie ten świat. Hosanna Bogu Dawidowemu. Kto święty niech przystąpi, kto nim nie jest niech czyni pokutę $(10,6)$. W dzień niedzielny Pana gromadźcie się by łamać chleb i dzięki czynić, wyznajcie swoje grzechy, aby wasza ofiara była czysta. Każdy człowiek, który ma zatarg $z$ bratem niech nie dołącza się zanim nie pojedna się, z obawy aby ofiara nie była sprofanowana". $(14,1-2)$. Podczas zgromadzenia czyniono wyznanie grzechów publiczne i wspólne. Nie ma mowy kiedy to czyniono, Imiesłów aorystu tu użyty wskazuje, że miało to miejsce przed komunią św. Nie jest też powiedziane w jaki sposób tego dokonywano. Nie chodziło tu raczej o modlitwę indywidualną, ale o wspólną ${ }^{10}$. Pewną wskazówkę może stanowić modlitwa przekazana przez Prima Clementis $(60,1-2)$. „Boże miłosierny i współczujący odpuść nam nasze nieprawości, niesprawiedliwości, nasze winy, nasze zaniedbania. Nie poczytuj żadnego $z$ grzechów sług twoich i służebnic, lecz oczyść nas oczyszczeniem Twojej prawdy i kieruj naszymi krokami abyśmy postępowali w świętości serca i czynili to, co jest dobre i miłe w Twoich ocżach" 11. Równocześnie zauważamy, że samo wyznanie było niewystarczające do godnego przyjęcia komunii św. Didache wymaga świętości indywidualnej - „kto święty... niech przystąpi". Podane są też racje. Są nimi:

a) obecność Boga

b) obawa przed sprofanowaniem ofiary

Ofiara zaś ulega profanacji jeżeli nie ma pojednania $z$ bratem. Wi-dzimy tu wyraźnie nawiązanie do Mt 5,23 nn o zawróceniu od ołtarza w wypadku ,gdy się ma coś przeciw bratu", jak również do 1 Kor $11,27 \mathrm{nn}$.

Myśl o wymaganiu świętości powróci także w ostrzeżeniu rzuconym przed komunią św. które spotykamy po raz pierwszy w Konstytucjach Apostolskich VII, 13, 13 ta hagia tois hagiosis - święte świętym.

W interesującym nas wypadku Didache na określenie wyznania

9 J. A. J u n g m a n n, dz. cyt. T. I. s. 42.

10 Por. B. Pos chmann, Paenitentia secunda (Theophaneia, I) Bonn 1940. s. $89 \mathrm{nn}$ : C. Vogel, Le pecheur et la penitence dans l'Eglise ancienne, Paris 1966. s. 15: W. R ordorf, La remission des peches selon la $D i-$ dache. „Irenikon” T. XLVI: 1973. s. 286.

11 Tłum. własne $\mathrm{z}$ fr. Sources chrétiennes 167. 1971. s. 199. 
grzechów używa się greckiego słowa prosexomologesis, które stanie się wkrótce ekshomologesis ${ }^{12}$. Jeśli weźmiemny pod uwagę, że rozwój pokuty poszedł w kierunku zindywidualizowania, będziemy tym bardziej skłonni sięgać do tego elementu jako do jednego z ezynników powstania apologii.

3. Wiemy również, że msza św. poprzedzona była modlitwą przygotowawczą. Ordo Romanus I mówi tylko o tym, że biskup modli się w ciszy. Natomiast Ordo Rom. X podaje uwagę: ,... inclinans se Deum pro peccatis suis deprecetur" 13. Znamienną jest też uwaga J ungmanna, że apologie na początku mszy św. spotykamy prawie we wszystkich liturgiach (Jun II, 39) ${ }^{14}$.

4. Nie obyło się także bez wpływu liturgii Kościoła na Wschodzie. W VI w. w Kościele Wschodnim spotykamy modlitwę nazwaną Proteleiai euchai (modlitwy przed uroczystością, na początku, wstępne). Modlitwa ta treścią przypomina apologie. Dlatego $\mathrm{Cab}$ rol twierdzi, że powstanie apologii nie obyło się bez wpływu tego typu modlitw liturgii wschodniej 15 .

5. Na powstanie apologii wpłynęły także jeszcze inne czynniki. Powstały one w Galii, w epoce, w której mnożono ryty, formuły. Są to czasy kiedy liturgia rzymska zostaje mocno zmodyfikowana przez silną liturgię galijską. Znalazło to wyraz $\mathrm{w}$ dramatyzowaniu liturgii w długich modlitwach, w alegoryzmie itp. ${ }^{16}$

6. Równocześnie jest to okres pewnej petryfikacji, kiedy wiele formuł staje się niezmiennymi, 'nienaruszalnymi. Czy dała tu znać w jakiś sposób tendencja improwizowana, sympatycznej swobody w służbie Bożej?

7. Powstanie i rozwój apologii, które w IX w. wchodzą do liturgii frankońsko-rzymskiej, a w XI w. osiągają swój zenit, związany jest bardzo zasadniczo z tendencjami antyariańskimi. Polemiki z Arianami prowadziły do przeakcentowania bóstwa Chrystusa. Bóstwo, wielkość Boga i nieogarnioność wysuwa się na pierwszy plan. Stanowisko to, jak wykazał to $\mathrm{Jung} \mathrm{mann}{ }^{17}$ pociagnęło za sobą duże konsekwencje w liturgii. Na konsekwencje o charakterze duszpasterskim wskazał Fr. A rnold ${ }^{18}$. W liturgii tendencja antyariańska wyraziła się między innymi w zaciemnieniu roli Chrystusa jako Pośrednika. Dotychczasowa jasna formuła Per Christum ustępuje miejsca doksolo-

12 W. R ordorf, La remission, art. cyt., s. 297.

13 M. Andrieu, Les Ordines Romani du haut moyen-age. Louvain 930. T. II. s. 353.

14 J. A. J ung man n, dz. cyt. T. II. s. 39.

15 F. Cabrol, dz. cyt. $2600-2601$.

16 Zob. J. A. Jung ma nn, dz. cyt. T. I. s. $111 \mathrm{nn}$.

17 J. A. J ungmann, Die Stellung Christi im liturgischen Gebet. Münster 1925. s. $223 \mathrm{nn}$.

18 F. Arnold, Dienst am Glauben. Das vordringliste Anliegen heutiger Seelsorge. Freiburg 1948. 
giom skierowanym do Chrystusa. Pamiętamy także, że właśnie w VIII w. powstaje prefacja o Trójcy św. Przyjmuje się także brzmienie doksologii Gloria Patri et Filio et Spiritui Sancto zamiast dotychczas użwanej Gloria Patri per Filium in Spiritu Sancto. W eucharystii upatrywano przede wszystkim dar z nieba, który trzeba podziwiać z daleka. Stąd używanie niekwaszonego chleba, małych hostii, przyjmowanie komunii św. na klęcząco. Jeżeli eucharystia to przede wszystkim bona gratia - laska z nieba, to pytano kiedy, w którym ,miejscu” we Mszy św. dokonuje się zstąpienie Boga (punktualistyczne pojmowanie mszy św.). Z takiego nastawienia wypłynęło również wprowadzenie Orate fratres. Wypadało bowiem aby celebrans przed wejściem do sancta sanctorum zwrócił się do wiernych z prośbą o modlitwę, by był godny złożyć ofiarę, pro quibus Tibi Offerimus" 19.

Powstaniu apologii sprzyjała także atrofia Kościoła w aspekcie społecznym ${ }^{20}$. Rola kapłana sprowadzającego Boga na ołtarz, realizującego obecność Chrystusa, już i tak silnie akcentowana, została podbudowana jeszcze pozycją społeczną duchowieństwa. Ze Mszy św. czyniono swoistego rodzaju disciplina arcani, nie dbając o udział wiernych. Chociaż pewne wysiłki w tym kierunku były.

Wśród przyczyn należy także wymienić teologię sakramentu pokuty, która nie była jeszcze należycie wypracowana (Okres dychotomii karolińskiej). Sakrament pokuty praktykowany był rzadko, nawet $\mathrm{w}$ zakonach do XI w. spowiadano się raz w roku.

8. G. Couilleau w swoim studium wskazał na przypisywanie wyznaniu $\mathrm{z}$ powodu wywoływanego zawstydzenia - erubescentia mocy gładzenia grzechu ${ }^{21}$.

9. W związku z powyższym warto kilka uwag poczynić w odniesieniu do znaczenia słowa confessio. O ile bowiem wyrażenie apologia zbliża się znaczeniem do angielskiego ,to apologize" o tyle słowo confessio bardzo często używane na określenie tego typu modlitwy może rzucić światło na funkcję zjawiska apologii.

Łacińskie wyrażenie confessio lub confiteri znaczy wyznać, wyznać jakąś rzeczywistość. W odniesieniu do prawdy, dobra będzie to proklamacja, w odniesieniu zaś do zła - wyznanie. Słowo hebrajskie ho deh 22 (chwalić, dziękować) zostało oddane przez Septuagintę przez ekshomologestai.

Starożytność chrześcijańska zachowała te dwa znaczenia (Orygenes, Bazyli, Anaștazy) wyznawać i dzięikować.

J. A. J ung m a n n, dz. cyt. T. I. s. $113 \mathrm{nn}$.

20 Tenże dz. cyt. T. I. s. $114,116$.

$21 \mathrm{G}$. Couilleau, Accusation de soi dans le monachisme antique. „La vie spirituelle" mai 1967. s. 309-314. oraz J. A. J ung mann, dz. cyt. T. I. s. 112 .

${ }_{22}$ Theologisches Wörterbuch zum Neuen Testament (Kittel). V Stuttgart 1954. s. $202-205$. 
Św. Hieronim zauważa: Confessio pro laude ponitur. (Expl ps. 135,1) Liczne samooskarżenia się u mnichów miały być wyrazem uwielbienia Boga. Etiam peccata - stawały się okazją chwały. W tym znaczeniu pojmujemy Confessiones - Wyznania sw. Augustyna ${ }^{23}$. Wczesne średniowiecze nadal zachowuje podwójne znaczenie. Modlitew̌nik $\mathrm{z}$ czasów Karola Wielkiego nosi znamienną nazwę Humilis Confessio (Wyd. W i l mart, Roma 1940). U P iot r a Lo m b a r d a confessio jest żalem i chwałą - accusativa - laudativa. Sw. Bernard z Clairveaux jakby lubuje się w wyrażeniu confessio ,Czy to przez confessio waszych grzechów, czy przez confessio chwały Bożej, całe wasze życie wyznaje Go" ${ }^{24}$. Następne dopiero wieki rozdzieliły te znaczenia.

Sw. Tomasz z Akwinu odróżnia:

a. confessio fidei - akt wiary

b. confessio gratiarum - w znaczeniu aktu czci

c. confessio peccatorum - akt pokuty ${ }^{25}$.

Confessio w pierwotnym znaczeniu przetrwało w pobożności pokutników z XI w. Pokutnicy Italscy biczując się śpiewali laudes. Podobnie w krajach Ameryki Eacińskiej tzw. alabanzas ${ }^{26}$.

\section{APOLOGIE WIERNYCH}

Zazwyczaj apologie odmawiane były przez celebransów. Ale nie wylącznie. Istnieje cały szereg apologii odmawianych przez wiernych. Miały one miejsce przede wszystkim przed przygotowaniem darów, po homilii, a często w konkluzji Modlitwy Powszechnej. Szczególne znaczenie miały apologie po homilii. Expositio antiquae liturgiae Gallicanae (VII w.) podaje, że po homilii następują ,preces ut audita apostoli praedicatione levitae pro populo deprecentur et sacerdotes prostrati ante Dominum pro peccatis populi intercedant". W skład apologii wchodziło m.in. Confiteor i Miseratur ${ }^{27}$. Jeszcze Ritus concelebrations z 1965 r. w n. 27 zauważa: ,post homiliam non datur absolutio". Ceremoniał biskupi (II, 39) przewidywał, że po kazaniu i odśpiewaniu przez diakona Confiteor Biskup zdejmował mitrę i stojąc odczytywal in tono orationis versus ad populum: Precibus et meritis... misereatur... indulgentiam, absolutionem et remissionem peccatorum... następnie udzielał błogosławieństwa et continuatur missa. Ryt ten co

23 J. L e cle r c q. La confession louonge de Dieu. „La vie spirituelle” mars 1968. s. 259.

24 In vig. Nativ. 2, 1. Opera omnia IV Roma 1960. s. 203-204.

25 Summ. Theol. IIa IIae q. 3 a. 1 ad l-um.

26 J. Le c le r c q. art. cyt. 206 s. 264.

27 S. Quasten. Expositio antiquae liturgiae Gallicanae Germano Parisiensi ascripta. Münster 1934. 16. oraz J. A. J u n g m a n n. dz. cyt. T. II. s. 268 . 
do treści odnajdujemy $u$ Durandusa 28 . Pochodzenie jego natomiast sięga rytu pojednania grzeszników w Wielki Czwartek. Ryt ten, zauważa Jungmann ${ }^{29}$, rozciągnięto nie tylko na innych wiernych ale także stosowano go w inne dni. Po kazaniu wierni, którzy pragnęli absolucji unosili ręce, wypowiadali spowiedź powszechną i otrzymy wali rozgrzeszenie. Przy tym pouczano ich, że ryt ten ma zastosowanie odnośnie „peccata gravia oblita vel ad peccata venialia”. Zwyczaj ten był powszechny w średniowieczu. Karol Boromeusz jeszcze wyraźnie przepisywał go proboszczom ${ }^{30}$.

Za pozostałość apologii należy uznać także Confiteor przed komunią św. 30a. Należy także wspomnieć o apologii wiernych na początku mszy św. Mówimy o tym na końcu, ponieważ w zasadzie akt pokuty na początku mszy posiadał charakter prywatny. Dotyczył celebransa i posługujących. Jungmann jednak zaznacza, że niekiedy również wierni brali udział w tym akcie pokuty. Miało to miejsce w Normandii, a także $w$ południowych Niemczech. Kapłan po Indulgentiam, względnie po ucałowaniu ołtarza zwracał się do wiernych i po odmówieniu przez nich Confiteor odmawiał modlitwę, której używał przy absolucji sakramentalnej 31 .

\section{ZANIK APOLOGII}

Apologie po osiągnięciu swego zenitu w w. IX-XI nagle znikły. Oczywiście nie obyło się bez wyjątków np. Missale z Seckau z 1170 r. podaje jeszcze apologie do odmawiania podczas Gloria, Credo, przed kazaniem, przed kanonem. Mszał Westminster (1370) zawiera 6 apologii do odmawiania w czasie „Chwała”. Mszały hiszpańskie z XVI w. podają apologie ad introitum altaris, lub ad introitum Missae. Pozostałością apologii są modlitwy: Aufer a nobis, Oramus Te Domine usunięte ze mszy przez nowe Ordo Missae z r. 1969, Suscipe sancta Trinitas, Summe sacerdos przygotowanie prywatne kapłana do Mszy, Placeat i inne 32 .

28 M. Andrieu. Le pontifical Romain III, 639. cyt. za J. A. Jung$\mathrm{mann}$. De actu paenitentiali infra Missam inserto conspectus historicus. „Ephemerides Liturgicae” vol. LXXX: 1966. s. 259.

29 zob. J.A. J ung m a n n. Die lateinischen Bussriten in ihrer geschichtlichen Entwicklung. Innsbruck 1932. s. 277-280, por. także tenże De actu poenitentiali... art. s. 259.

30 Acta Ecclesiae Mediolanensis. Bergomi 1938. 737 cyt. za J. A. J u n gman n. De actu poenitentiali... art. cyt. s. 259.

30a Ordo Cassinensis z XI w. wspomina wśród 'modlitw przygotowawczych do komunii św. Confiteor po którym następuje Misereatur. XIIXIII w. zwyczaj ten rozpowszechnił się w zakonach. Od Piusa zaś V stał się powszechną praktyką. Codex rubricarum z 1960 zaniechał tej praktyki.

31 J. A. J ung $\mathrm{m}$ a n n. dz. cyt. T. II. s. $57 \mathrm{nn}$.

32 Tenże dz. cyt. T, I. s. 111 przyp. 24. 


\section{SAKRAMENTALNY CHARAKTER APOLOGII?}

Z kolei należy ustosunkować się do problemu jaki charakter posiadały apologie: sakramentalny, czỷ też tylko walor sakramentaliów. Opinie autorów są podzielone.

B. Poschmann sądzi, że apologie posiadały moc gładzenia grzechów powszednich ${ }^{33}$. K. Adam powołując się na Didache 14,1 przypisuje im walor gładzenia wszystkich grzechów, które "nie prowadzą do śmierci” i uważa apologie za normalną formę pokuty w Kościele czasów apostolskich ${ }^{34}$. J. Jungmann podkreśla, że zagadnienie to należy rozpatrywać na tle epoki. Niewątpliwie był to złoty wiek absolucji generalnych sakramentalnych ${ }^{35}$. Nie było jeszcze scholastycznych uściślen i restrykacji. Chociaż w ocenie dawnych zwyczajów należy zachować daleko idącą ostrożność, niemniej jednak istnieją pewne elementy, które bliżej określają charakter danego zjawiska. I tak w odniesieniu do apologii na początku mszy św. autor podkreśla, iż spotykamy źródła, które mówią o dołączaniu do wyznania grzechów odpowiedniej pokuty, co wskazywałoby na traktowanie tego aktu jako sakramentalny. Powołując się na Pontyfikał Duranda akcentuje istnienie następującego zwyczaju. W wypadku gdy we mszy św. uczestniczy biskup, kapłan zwracał się do niego ze slowami: „Iudicium pro peccatis meis". Biskup wyznaczał mu pokutę Ave, Pater noster lub inną. To samo czynił kapłan w odniesieniu do biskupa, który mu wyznaczał pokutę, względnie do innego obecnego na mszy św. ${ }^{36}$. Warto tu podkreślić, że niekiedy również wierni brali udział w tym akcie pokuty. Św. Tomasz z Akwinu poświęcił specjalną pracę formie rozgrzeszenia i zajął wyraźne stanowisko ,...quod in quibusdam absolutionibus quas Ecclesia facit in Prima et in Completorio, ante Missam et post praedicationem, secundum morem Romanae Ecclesiae, et in die Cinerum et Coenae Domini, non fit absolutio per orationem indicativam sed deprecativam... huiusmodi absolutiones non sunt sacramentales, sed sunt quaedam orationes, quibus dicuntur veniala peccata dimitti" ${ }^{37}$. Pomimo tak jasno wyrażonego stanowiska Sacerdotale używane w Rzymie z r. $1555^{38}$ czy też Sacerdotale z czasów po soborze Trydenckim

33 B. Pos chm a n n. Poenitentia secunda. Bonn 1940, s. 88-92.

34 Bussdisziplin LThK II. 1931. 657.

35 J. A. J ung mann dz. cyt. T. II. s. 56.

36 M. Andrieu. Le Pontifical Romain au moyen-age. Citta del Vaticano T. 3. Le Pontifical de G. Durand s. 643, zob. także A. No c e n t. L'acte penitentiel du nouvel "Ordo Missae" sacrament ou sacramental? „Nouvelle Revue Theologique” T. 91: 1969, s. 969; zob. także J. A. Jungmann. dz. cyt. T. II. s. 57 dopisek 63.

37 De forma absolutionis c. 2: zob. B. Poschmann. Die Abendländische Kirchenbusse im frühen Mittelalter. Wrocław 1930. s. 228.

38 Sacerdotale iuxta S. Romane ecclesie et aliarum ecclesiarum ex apostolicae bibliothece ac sanctorum patrum iurium. Venetiis apud Petrum Bosellum 1555, I-IV, tekst aktu żalu przed przygotowaniem darów 76r77r. cyt. za A. N o c e n t. L'acte Pénitentiel... art. cyt. s. 960. 
(1585) ${ }^{39}$ przewiduje następujący przebieg apologii po homilii. „Następnie czyni ogólne wyznanie wobec ludu, gdy wszyscy klęczą w następujących słowach: Uczyńcie znak krzyża św. wraz ze wzbudzeniem skruchy za grzechy wasze i powtarzajcie za mną słowa: mówi w języku ludowym: Spowiadam się Bogu Wszechmogącemu... (wylicza długą serię imion świętych) oraz Tobie Ojcze, że ciężko zgrzeszyłem mową, złym uczynkiem, myślą, krzywoprzysięstwem, niegodziwym zamiarem, radością z grzechu, oglądaniem, słuchaniem, powonieniem, smakiem i dotykiem, uczyniłem wiele, czego nie należało czynić i wiele opuściłem dobra, które powinienem był wykonać; z powodu niedbalstwa mojego zgorszyłem też wielu złym moim przykładem, dałem okazję do grzechu i do niego drugich doprowadziłem. $\mathrm{Za}$ te wszystkie moje jakiekolwiek grzechy i przestępstwa moje, których się dopuściłem, popełniłem i za wszystko zło, do którego się przyczyniłem od godziny mego chrztu św. aż do obecnego momentu i za opuszczenie dobra, które mogłem wykonać - wyznaję moją winę, moją winę, moją bardzo wielką winę i błagam Wszechmogącego Boga, aby przez swoje przeobfite miłosierdzie przebaczyl mi wszystkie grzechy, a Ty Ojcze racz mnie władzą sprawowaną w imieniu Boga i Kościoła rozgrzeszyć oraz nałożyć zbawienną pokutę oraz modlić się za mnie nędznego grzesznika" (Następuje ten sam tekst w języku włoskim). Wtenczas kapłan z podniesioną prawicą nad ludem mówi: „Niech wam przebaczy Wszechmogący Bóg. Każdy $z$ was dla odpuszczenia grzechów swoich niech odmówi Ojcze nasz i 3 razy Zdrowaś Maryja za jedność pokój i zgodę świętej Matki Kościoła i za zbawienie całego ludu chrześcijańskiego, każdy też niech odmówi 5 razy Ojcze nasz i tyle razy Zdrowaś Maryjo, za wszystkich wiernych zmarłych, a za dusze w czyśćcu się znajdujące 3 razy Ojcze nasz i 3 Zdrowaś Maryjo. Niech się zmiłuje nad wami Bóg wszechmogący, a odpuściwszy wam grzechy wasze doprowadzi was wraz ze Swiętymi swoimi do życia wiecznego. Amen.

Przebaczenia, odpuszczenia i darowania wszystkich grzechów, życia świętego i błogosławionej śmierci niech wam udzieli Wszechmogący i miłosierny Bóg. Amen.

A błogosławieństwo Boga wszechmogącego Ojca i Syna + i Ducha + Swiętego niech zstąpi na was i pozostanie na zawsze. Amen". Tym co badaczowi nasuwa myśl o sakramentalnym charakterze tych modltw w ówczesnym czasie jest najpierw obecność formuły Indulgentiam, którą uważa się za pierwotną formę rozgrzeszenia. Towarzyszący następnie tej modlitwie znak krzyża rozumiany jest jako substytucja nałożenia rąk, a wreszcie nałożenie pokuty zadośćczyniącej ${ }^{40}$.

${ }^{39}$ Sacerdotale Romanum ac consuetidinem S. Romane Ecclesie... A. No c e n t. L'acte Penitentiel... art. cyt. s. 960.

${ }_{40} \mathrm{~J}$. A. Jungmann. Die lateinische Bussriten... Die Absolutionsformeln s. $201 \mathrm{nn}$. a także s. 217, 275-295. tenże Missarum sollemnia. T. II. s. 57 nn: A. N o ç en t. L'acte Pénitentiel... art. art. cyt. s. 967. 
Zagadnienie charakteru apologii wiernych na pewno nie należy do zagadnień czysto teoretycznych. Może bowiem rzucić światło na odpowiednie traktowanie aktu pokuty w obecnym układzie Najświętszej Ofiary, co w konsekwencji pomnożyłoby ilość wiernych pełnie uczestniczących we Mszy św.

Poznań

KS. BOGUSEAW NADOLSKI TCHR.

\section{Ks. Bolesław Margański}

\section{FORMY POSAKRAMENTALNEGO GLADZENIA GRZECHÓW W KOŚCIOLACH WSCHODNICH}

Kościoły Wschodnie, obok pokuty publicznej i prywatnej, wypracowały i do obecnej chwili zachowują pewne formy pokutne, przeznaczone dla zgromadzenia liturgicznego, dla wspólnoty jako takiej. Te wspólnotowe praktyki pokutne czerpią swój początek $\mathrm{z}$ okresu starożytności lub średniowiecza. Jedne $z$ nich są okazyjne lub roczne, (praktyki mnichów św. Pachomiusza, genuflexio...), inne zaś codzienne, złączone z Liturgią Godzin lub ze Mszą św.

Rozważmy przeto ich zasadnicze formy i ich walor sakramentalny.

I. PODSTAWOWE FORMY WSPÓLNOTOWYCH PRAKTYK POKUTNYCH

Do najbardziej rozpowszechnionych rytów pokutnych Kościoła Wschodniego należą: ryt okadzenia u Koptów, hussoyé lub sedré oraz aphes, anes, synchóréson w obrządkach syro-zachodnich, ryt maronicki po Pater noster, ryt okadzenia i pojednania opartego na Modlitwie Pańskiej w obrządkach chaldejsko-nestoriańskich oraz ryt przyklęknięcia związanego z Pięćdziesiątnicą jako praktyka wspólna dla wielu Kościolów. Omawiając poszczególne ryty, zwróćmy uwagę na.dane historyczne, teologiczne i liturgiczne.

1. Ryt okadzenia u Koptów.

Wbrew pewnym opiniom o apostolskich początkach tego rytu, hi- storycy liturgii utrzymują, iż praktyka pokutnego okadzenia jest nieznana całej starożytności chrześcijańskiej ${ }^{1}$. W rzeczywistości istnieje brak świadectw z pierwszych wieków. Albowiem ani Orygenes, objaśniejący opis okadzenia czynionego przez Aarona, ani Żywot św. Pa-

1 Por. E. Ren a udot, La perpétuité de la foi de l'Eglise catholique sur les Sacraments, v. III, Paris 1841, pp. 848-852. 